\title{
EFFECT OF IMMUNISATION WITH HEAT-KILLED MICRO- ORGANISMS ON TRANSPLANTATION IMMUNITY TO ADENOVIRUS-12-INDUCED TUMOUR CELLS
}

\author{
R. C. Rees AND C. W. Potter \\ Department of Medical Microbiology, The University of Sheffield Medical School, \\ Beech Hill Road, Sheffield
}

ANIMALS immunised with the BCG strain of Mycobacterium bovis, or with fractions of BCG, are resistant to the transplantation of tumours (Old, Clarke and Benacerraf, 1959; Weiss, Bonhag and De'Ome, 1961; Weiss, Bonhag and Leslie, 1966). Similar findings have been described with Corynebacterium parvum (Smith and Woodruff, 1968; Fisher, Grace and Mannick, 1970). Bordetella pertussis, on the other hand, has given variable results, producing either immunity (Malkiel and Hargis, 1961; Cohen and Tissot, 1963), or increased susceptibility to tumour challenge (Floersheim, 1967; Hirano et al., 1967).

Cell-free extracts prepared from adenovirus-12-induced tumours of CBA mice possess immunising activity in CBA mice against the transplantation of the same tumour (Potter and Oxford, 1970; Brown, Potter and Oxford, 1972). The addition of $M$. butyricum increases significantly this immunising activity of the tumour extract (Rees and Potter, 1972). The present paper reports our further investigations of this phenomenon with other microbes, including $B$. pertussis, and a study of the nature of the immune response by adoptive transfer techniques.

\section{MATERIALS AND METHODS}

Adenovirus-12 tumour cells. Groups of CBA mice, given subcutaneous injections of transplantable, adenovirus-12-induced tumour cells, were killed when the tumours had grown to a diameter of $10-15 \mathrm{~mm}$. The tumours were removed and cell suspensions were prepared as described previously (Potter and Oxford, 1970). The cell count was adjusted to $5 \times 10^{6}$ viable cells per $\mathrm{ml}$ in Eagle's minimum essential medium containing $2 \%$ inactivated calf serum, and the final suspension was used immediately for immunisation experiments.

Tumour-cell extracts. Tumours were removed from 10-30 CBA mice and minced with a scalpel. Fragments were disrupted further by brief homogenisation in a Waring blender and by freezing and thawing (at $-80^{\circ} \mathrm{C}$ and $20^{\circ} \mathrm{C}$ respectively). The suspension was centrifuged at $100,000 \mathrm{~g}$ for 1 hour (Potter and Oxford, 1970), and the supernatant was then filtered through a millipore membrane of $0.45 \mu$ pore size. The final extract was derived from approximately $3 \times 10^{7}$ tumour cells per $\mathrm{ml}$ and contained $1.2-1.5 \mu \mathrm{g}$ of total protein per $\mathrm{ml}$ (Lowry et al., 1951). Pools of extract were stored at $-80^{\circ} \mathrm{C}$ in $2-\mathrm{ml}$ amounts. Tumour extract was not standardised with regard to immunising activity but the same pool of extract was used for all mice in a given experiment. Different batches of extract have been shown to vary in their ability to immunise mice against tumour challenge (Rees and Potter, 1973).

Micro-organisms. B. pertussis, Escherichia coli serotype 055, Staphylococcus aureus Oxford, Listeria monocytogenes, Coryne. parvum and Candida albicans were originally 
obtained from the National Collection of Type Cultures, Colindale, London, and have been maintained in our laboratories for several years. They were grown on appropriate solid media at $37^{\circ} \mathrm{C}$ and then carefully flushed from the agar surface with phosphate-buffered

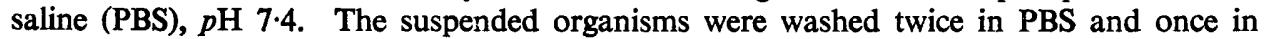
distilled water by centrifugation at 3000 r.p.m. for $15 \mathrm{~min}$., resuspended to a concentration of $10 \%(\mathrm{v} / \mathrm{v})$ and autoclaved at $115^{\circ} \mathrm{C}$ for $10 \mathrm{~min}$. After drying over phosphorous pentoxide in a dessicator they were stored at $4^{\circ} \mathrm{C}$. Before use, the heat-killed, dried organisms were ground with a pestle and mortar and resuspended in PBS to a concentration of $0.5 \mathrm{mg}$ per ml, unless otherwise stated. The preparation of $M$. butyricum extracts has been described previously (Rees and Potter, 1972).

Spleen-cell suspensions. The spleens were removed from batches of normal mice or from mice that had been immunised by three weekly subcutaneous doses of tumour extract (Rees and Potter, 1973). The spleens were finely minced with a scalpel and suspended in Medium 199. Single cell suspensions were obtained by extruding the fragments through a syringe without a needle and then filtering through sterile cotton gauze. Each spleen cell suspension was centrifuged at $100 \mathrm{~g}$ for $10 \mathrm{~min}$., and the supernatant was discarded and replaced by distilled water ( $3 \mathrm{ml}$ of water per $\mathbf{0 . 1} \mathrm{ml}$ of packed spleen cells) for $30 \mathrm{~s}$ to lyse red blood cells. Isotonic conditions were then restored by adding an equal volume of $0.3 \mathrm{M}-\mathrm{NaCl}$. The cells were next washed three times with Medium 199, resuspended in Medium 199 to the desired concentration, and inoculated immediately into mice.

Mouse sera. Mice were killed and blood was collected from the thoracic cavity, into which it had been allowed to drain after resecting the lungs. The blood was kept at $4^{\circ} \mathrm{C}$ for 12 hours and then centrifuged at $2000 \mathrm{~g}$ for $10 \mathrm{~min}$. Serum from groups of normal or immunised mice was pooled. The pools were stored at $-20^{\circ} \mathrm{C}$.

Transplant-immunity tests. These were carried out in CBA mice from a closed, randomly bred colony. The mice were weaned at 21 days, and immediately started on immunisation schedules. Groups of 10-20 mice were given subcutaneous inoculations of $0.1 \mathrm{ml}$ of tumour extract, mixed with an equal volume of either PBS or a suspension of a micro-organism, at weekly intervals for 3 weeks; further groups of mice received either $0.1 \mathrm{ml}$ of micro-organism suspension mixed with $0.1 \mathrm{ml}$ of PBS, or $0.2 \mathrm{ml}$ of PBS alone. Two weeks after the third dose each mouse received a subcutaneous injection of $0.1 \mathrm{ml}$ of tumour cell suspension $\left(5 \times 10^{5}\right.$ viable tumour cells); this was approximately ten $50 \%$ tumour-producing doses. Mice were examined for tumours weekly for 5 weeks; new tumours rarely appeared after this time.

Adoptive transfer experiments. (a) Cell transfer. Spleen-cell suspensions were prepared from normal CBA mice, from mice immunised by three weekly doses of $0.1 \mathrm{ml}$ of tumour extract, or from mice given three $0.1 \mathrm{ml}$ doses of tumour extract mixed with an equal volume of the relevant micro-organism. Spleens were removed 2 weeks after the third inoculation. Spleen cell suspensions were prepared at a concentration of $1.5 \times 10^{7}$ cells per $0.1 \mathrm{ml}$ and mixed with an equal volume of tumour cells containing $1.0 \times 10^{6}$ cells per $0.1 \mathrm{ml}$; this gave a lymphocyte to tumour cell ratio of 15 to 1 . Groups of 15 normal CBA mice were given subcutaneous injections of $0.1 \mathrm{ml}$ of the lymphocyte-tumour-cell mixture, and the subsequent occurrence of tumours was recorded twice weekly for 5 weeks. (b) Passive serum transfer. The mice used for the cell transfer experiments were bled at the time of spleen removal, and the sera from the normal and immunised mice were separately pooled. Each serum pool was injected intraperitoneally, in $0 \cdot 1-\mathrm{ml}$ amounts, into 15 normal CBA mice and this was repeated after 24 hours and 72 hours. On the 4 th day, each mouse also received a subcutaneous inoculation of $5 \times 10^{5}$ tumour cells. They were examined for tumour growth twice weekly for 5 weeks.

\section{RESULTS}

\section{Transplantation-immunity studies}

The effect of immunisation with cell-free extract of adenovirus-12-induced tumour cells or with extract plus $M$. butyricum on the susceptibility of CBA mice 
to transplantation of the tumour cells is shown in table I. The incidence of tumours in mice immunised with tumour extract alone was significantly lower than in control, non-immunised mice $(\mathrm{P}<0.05)$, and still lower in the mice given tumour extract plus $M$. butyricum. The decreased incidence of tumours in the latter animals, as compared with those immunised with tumour extract only, was also significant $(\mathrm{P}<0.05)$. The somewhat greater incidence of tumours in mice immunised with $M$. butyricum alone than in the control animals was not significant. Similar but less striking results were obtained with Coryne. parvum (table I). However, although the findings with this organism were

TABLE I

Incidence of successful tumour transplantation in $C B A$ mice immunised with tumour extract and/or Mycobacterium butyricum or Corynebacterium parvum

\begin{tabular}{|c|c|c|c|c|c|}
\hline \multirow[t]{2}{*}{ Mice immunised with } & \multicolumn{5}{|c|}{$\begin{array}{l}\text { Incidence (and final percentage) of successful } \\
\text { tumour challenge after week }\end{array}$} \\
\hline & 1 & 2 & 3 & 4 & 5 \\
\hline $\begin{array}{l}\text { tumour extract } \\
\text { tumour extract }+M . \text { butyricum } \\
M . \text { butyricum } \\
\text { PBS }\end{array}$ & $\begin{array}{l}0 / 16^{*} \\
0 / 18 \\
0 / 17 \\
0 / 18\end{array}$ & $\begin{array}{l}0 / 16 \\
0 / 18 \\
6 / 17 \\
2 / 18\end{array}$ & $\begin{array}{r}4 / 16 \\
0 / 18 \\
14 / 17 \\
12 / 18\end{array}$ & $\begin{array}{r}7 / 16 \\
0 / 18 \\
16 / 17 \\
13 / 18\end{array}$ & $\begin{array}{l}7 / 16(44) \\
1 / 18(5 \cdot 5) \\
17 / 17(100) \\
14 / 18(78)\end{array}$ \\
\hline $\begin{array}{l}\text { tumour extract } \\
\text { tumour extract }+ \text { Coryne. parvum } \\
\text { Coryne. parvum } \\
\text { PBS }\end{array}$ & $\begin{array}{l}0 / 14 \\
0 / 10 \\
0 / 14 \\
0 / 11\end{array}$ & $\begin{array}{l}2 / 14 \\
0 / 10 \\
2 / 14 \\
4 / 11\end{array}$ & $\begin{array}{l}6 / 14 \\
1 / 10 \\
7 / 14 \\
9 / 11\end{array}$ & $\begin{array}{r}9 / 14 \\
3 / 10 \\
8 / 14 \\
10 / 11\end{array}$ & $\begin{array}{l}9 / 14(65) \\
4 / 10(40) \\
10 / 14(71) \\
11 / 11(100)\end{array}$ \\
\hline
\end{tabular}

reproduced in a further experiment the differences obtained in tumour incidence before and after immunisation did not reach statistically significant levels.

The effect of immunisation with $B$. pertussis, $E$. coli or $S$. aureus, alone and with tumour extract, on the susceptibility of CBA mice to the transplantation of adenovirus-12-induced tumour is shown in table II. With all three organisms, immunisation with the tumour extract-bacterium mixture produced an increase in the incidence of tumours, compared with tumour extract alone. However, this increase was statistically significant at 3 and 4 weeks but not at 5 weeks, after tumour challenge, in the case of $B$. pertussis, and only at 3 weeks in the case of the other two organisms. Immunisation with $B$. pertussis alone led to an increase in the number of mice with tumours, compared with the control, non-immunised mice, but at no time was this difference statistically significant. There was no increase in tumour susceptibility after immunisation with $E$. coli or $S$. aureus alone.

The effect of varying the immunising dose of $B$. pertussis, when given alone and with tumour extract, was also investigated. The results are presented in table III. Mice immunised with three weekly doses of tumour extract mixed 
TABLE II

Incidence of successful tumour transplantation in $C B A$ mice immunised with tumour cell extract and/or Bordetella pertussis, Escherichia coli or Staphylococcus aureus

\begin{tabular}{|c|c|c|c|c|c|}
\hline \multirow{2}{*}{ Mice immunised with } & \multicolumn{5}{|c|}{$\begin{array}{l}\text { Incidence (and final percentage) of successful } \\
\text { tumour challenge after week }\end{array}$} \\
\hline & 1 & 2 & 3 & 4 & 5 \\
\hline $\begin{array}{l}\text { tumour extract }+B \text {. pertussis } \\
B \text {. pertussis }\end{array}$ & $\begin{array}{l}0 / 20^{*} \\
0 / 13\end{array}$ & $\begin{array}{l}3 / 20 \\
0 / 13\end{array}$ & $\begin{array}{l}14 / 20 \dagger \\
11 / 13\end{array}$ & $\begin{array}{l}18 / 20 \\
13 / 13(100\end{array}$ & $\begin{array}{c}19 / 20(95) \\
\quad \ldots\end{array}$ \\
\hline $\begin{array}{l}\text { tumour extract }+E . \text { coli } \\
E . \text { coli }\end{array}$ & $\begin{array}{l}0 / 20 \\
0 / 20\end{array}$ & $\begin{array}{l}2 / 20 \\
2 / 20\end{array}$ & $\begin{array}{l}12 / 20 \dagger \\
13 / 20\end{array}$ & $\begin{array}{l}17 / 20 \\
16 / 20\end{array}$ & $\begin{array}{l}17 / 20(85) \\
16 / 20(80)\end{array}$ \\
\hline $\begin{array}{l}\text { tumour extract }+S . \text { aureus } \\
S . \text { aureus }\end{array}$ & $\begin{array}{l}0 / 20 \\
0 / 20\end{array}$ & $\begin{array}{l}2 / 20 \\
4 / 20\end{array}$ & $\begin{array}{c}12 / 20 \dagger \\
8 / 20\end{array}$ & $\begin{array}{l}15 / 20 \\
14 / 20\end{array}$ & $\begin{array}{l}16 / 20(80) \\
19 / 20(95)\end{array}$ \\
\hline $\begin{array}{l}\text { tumour extract } \\
\text { PBS }\end{array}$ & $\begin{array}{l}0 / 17 \\
0 / 20\end{array}$ & $\begin{array}{l}0 / 17 \\
0 / 20\end{array}$ & $\begin{array}{l}1 / 17 \\
9 / 20\end{array}$ & $\begin{array}{r}9 / 17 \\
17 / 20\end{array}$ & $\begin{array}{l}12 / 17(70) \\
18 / 20(90)\end{array}$ \\
\hline
\end{tabular}

* Number with tumours.

Number challenged

$\dagger$ Incidence significantly greater $(P<0.05)$ than in mice immunised with tumour extract only.

TABLE III

Incidence of successful tumour transplantation in $C B A$ mice immunised with tumour extract and/or various concentrations of Bordetella pertussis

\begin{tabular}{|c|c|c|c|c|c|}
\hline \multirow{2}{*}{ Mice immunised with } & \multicolumn{5}{|c|}{$\begin{array}{l}\text { Incidence (and final percentage) of successful } \\
\text { tumour challenge after week }\end{array}$} \\
\hline & 1 & 2 & 3 & 4 & 5 \\
\hline \multirow{3}{*}{$\begin{array}{l}\text { tumour extract }+B \text {. pertussis } \\
\quad(0.1 \mathrm{mg} \text { per ml }) \\
\text { tumour extract }+B . \text { pertussis } \\
\quad(0.5 \mathrm{mg} \text { per ml }) \\
\text { tumour extract }+B \text {. pertussis } \\
(2.5 \mathrm{mg} \text { per } \mathrm{ml})\end{array}$} & $0 / 16^{*}$ & $0 / 16$ & $0 / 16$ & $1 / 16$ & $5 / 16(35)$ \\
\hline & $0 / 16$ & $1 / 16$ & $6 / 16$ & $8 / 16$ & $9 / 16(53)$ \\
\hline & $0 / 17$ & $3 / 17$ & $6 / 17$ & $7 / 17$ & $8 / 17(47)$ \\
\hline $\begin{array}{l}\text { B. pertussis }(0.1 \mathrm{mg} \text { per } \mathrm{ml}) \\
\text { B. pertussis }(0.5 \mathrm{mg} \text { per } \mathrm{ml}) \\
\text { B. pertussis }(2.5 \mathrm{mg} \text { per } \mathrm{ml})\end{array}$ & $\begin{array}{l}0 / 12 \\
0 / 18 \\
0 / 18\end{array}$ & $\begin{array}{l}1 / 12 \\
1 / 18 \\
4 / 18\end{array}$ & $\begin{array}{l}5 / 12 \\
3 / 18 \\
8 / 18\end{array}$ & $\begin{array}{r}8 / 12 \\
6 / 18 \\
11 / 18\end{array}$ & $\begin{array}{r}9 / 12(75) \\
6 / 18(33) \\
11 / 18(61)\end{array}$ \\
\hline $\begin{array}{l}\text { tumour extract } \\
\text { PBS }\end{array}$ & $\begin{array}{l}0 / 18 \\
0 / 16\end{array}$ & $\begin{array}{l}0 / 18 \\
0 / 16\end{array}$ & $\begin{array}{l}0 / 18 \\
4 / 16\end{array}$ & $\begin{array}{l}1 / 18 \\
9 / 16\end{array}$ & $\begin{array}{r}4 / 18(22) \\
10 / 16(62)\end{array}$ \\
\hline
\end{tabular}

* Number with tumours.

Number challenged 
with $B$. pertussis, $0.5 \mathrm{mg}$ or $2.5 \mathrm{mg}$ per $\mathrm{ml}$, and subsequently challenged with $5 \times 10^{5}$ tumour cells showed a higher incidence of tumours than mice given tumour extract only, as in the earlier experiments. With the lower concentration of $0.1 \mathrm{mg}$ per $\mathrm{ml}$, the tumour incidence was not significantly different from that in mice immunised with tumour extract alone. Immunisation with $B$. pertussis alone, over the concentration range $0 \cdot 1-2 \cdot 5 \mathrm{mg}$ per $\mathrm{ml}$, did not produce a significant change in the incidence of tumours when compared with nonimmunised mice.

Immunisation with L. monocytogenes and Cand. albicans, alone or together with tumour extract, was not found to influence the susceptibility of mice to tumour transplantation.

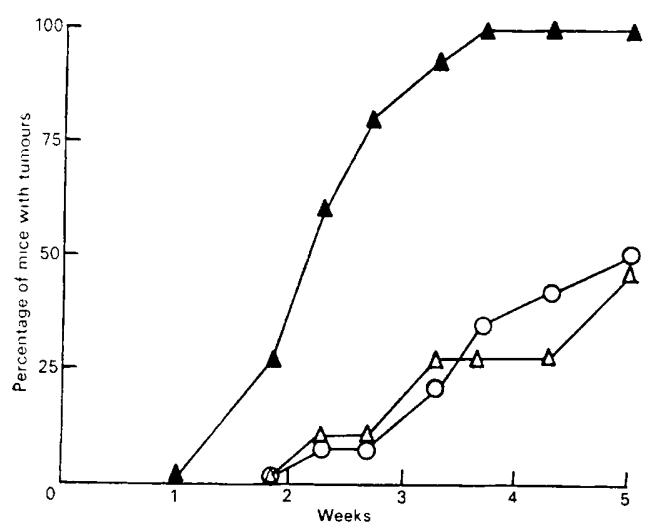

FIG. 1.--Incidence of successful tumour transplantation in CBA mice challenged with adenovirus-12-induced tumour cells plus spleen cells. $\triangle=$ spleen cells from mice immunised with tumour extract; $\mathrm{O}=$ spleen cells from mice immunised with tumour extract plus Mycobacterium butyricum; $\mathbf{\Delta}=$ spleen cells from normal mice.

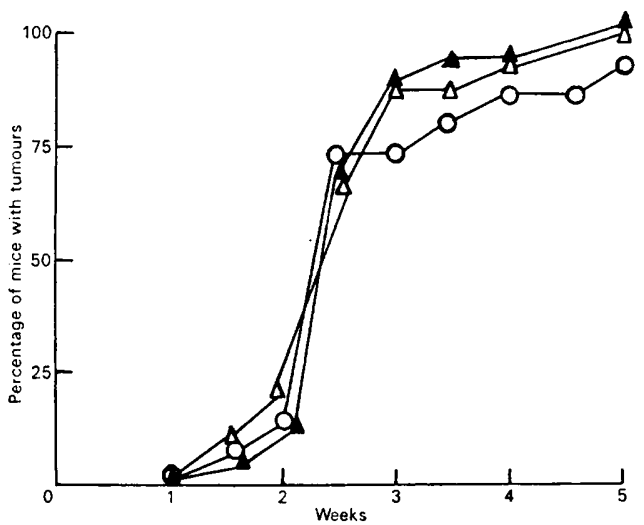

FIG. 2.-Incidence of successful tumour transplantation in CBA mice passively immunised with mouse serum and then challenged with adenovirus-12-induced tumour cells. $\triangle=$ serum from mice immunised with tumour extract; $O=$ serum from mice immunised with tumour extract plus Mycobacterium butyricum; $\boldsymbol{\Lambda}=$ serum from normal mice.

\section{Adoptive transfer experiments}

Mice given injections of tumour cells mixed with spleen cells which had been taken from mice immunised either with tumour extract or with tumour extract plus $M$. butyricum developed significantly fewer tumours than mice given tumour cells mixed with normal spleen cells $(\mathrm{P}<0.05)$ (fig. 1). However, there was no obvious difference between spleen cells from mice immunised with tumour extract plus $M$. butyricum and those from mice immunised with tumour extract alone in their ability to prevent tumour growth.

In passive immunisation experiments, serum obtained from mice immunised with tumour extract or tumour extract plus $M$. butyricum neither enhanced nor depressed susceptibility to tumour transplantation, when compared with serum from normal, untreated mice (fig. 2).

The incidence of tumours in mice given spleen cells from animals immunised with tumour extract or tumour extract plus $B$. pertussis was significantly less 
than in mice given normal spleen cells (fig. 3). The somewhat greater susceptibility to tumour transplantation of the mice given spleen cells from animals immunised with tumour extract and $B$. pertussis, compared with those mice given spleen cells from animals immunised with tumour extract only, suggests that the cellular immunity response to tumour extract is depressed by $B$. pertussis. Passive immunisation with serum from animals immunised with tumour extract or tumour extract plus $B$. pertussis did not alter the incidence of tumour transplantation, compared with mice given normal serum before tumour challenge (fig. 4).

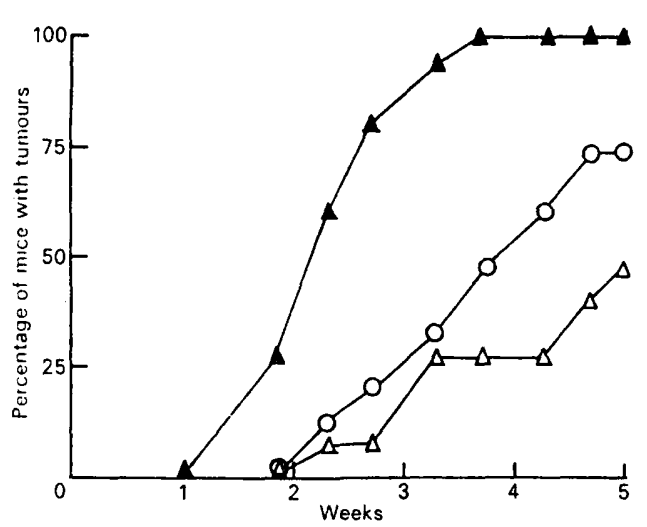

FIG. 3.--Incidence of successful tumour transplantation in CBA mice challenged with adenovirus-12-induced tumour cells plus spleen cells. $\triangle=$ spleen cells from mice immunised with tumour extract; $\bigcirc=$ spleen cells from mice immunised with tumour extract plus Bordetella pertussis; $\mathbf{\Lambda}=$ spleen cells from normal mice.

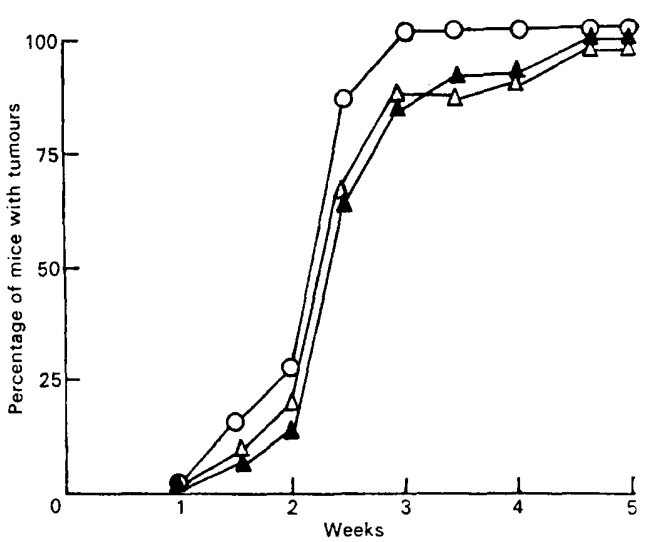

FIG. 4.-Incidence of successful tumour transplantation in mice passively immunised with mouse serum and then challenged with adenovirus-12-induced tumour cells. $\triangle=$ serum from mice immunised with tumour extract; $0=$ serum from mice immunised with tumour extract plus Bordetella pertussis; $\mathbf{\Delta}=$ serum from normal mice.

\section{Discussion}

The present study confirms that immunisation with a cell-free extract of adenovirus-12-induced mouse tumour renders CBA mice relatively immune to subsequent challenge with the tumour cells (Potter and Oxford, 1970; Brown et al., 1972). At the same time, the immunising activity of the tumour extract is variably affected by the addition of micro-organisms. It is improved by $M$. butyricum, a result obtained by earlier workers with other mycobacteria (Weiss et al., 1961,1966), and possibly also by Coryne. parvum. Adoptive transfer tests indicated that the immunity is cell mediated. However, although transplantation immunity tests readily showed the improved efficiency of the tumour extract- $M$. butyricum mixture over tumour extract alone in protecting against tumour transplantation, the adoptive transfer of immune spleen cells failed to demonstrate this difference. This may indicate relative insensitivity of the adoptive transfer technique compared with transplantation immunity.

A non-specific resistance to tumour cell challenge has been described in animals immunised with BCG or methanol extracts of BCG (Old et al., 1959; 
Weiss et al., 1961, 1966), and it has been proposed that this is due to non-specific stimulation of the reticulo-endothelial system (Nicol, McKelvie and Druce, 1961; Old et al., 1961). Others have reported a similar, non-specific resistance after immunisation with Coryne. parvum (Smith and Woodruff, 1968; Fisher et al., 1970; Woodruff, Inchley and Dunbar, 1972). Our findings with Coryne. parvum were inconclusive.

Earlier studies on the effect of immunisation with $B$. pertussis on tumour transplantation have been conflicting. Floersheim (1967) and Hirano et al. (1967) found increased susceptibility, whereas others obtained increased resistance of a non-specific type (Malkiel and Hargis, 1961; Cohen and Tissot, 1963). The present study showed enhanced susceptibility to tumour challenge after immunisation with both $B$. pertussis alone and $B$. pertussis plus tumour extract. Our results are not strictly comparable with those of the earlier workers, since they used pertussis vaccine, not a heat-killed suspension of the organism, and gave only a single, intraperitoneal injection, rather than three, weekly, subcutaneous doses, before challenging with tumour cells. The dried weight of organism used by us also cannot be compared directly with that present in pertussis vaccine, but varying the immunising dose of organisms over a 25-fold range failed to produce resistance to tumour cell transfer. Although the enhancing effect of the organism disappeared at low concentrations no evidence was obtained, at any of the concentrations used, of specific or nonspecific resistance.

Orlando et al. (1972) have recently reported that immunisation with a mixture of pertussis vaccine, methylated bovine serum albumen and irradiated tumour cells enhances tumour growth. This effect was shown, by passive transfer experiments, to be due to a factor or factors present in serum. The present experiments with mice immunised with heat-killed $B$. pertussis plus tumour extract indicate that the increased susceptibility to tumour growth is due to depressed cell-mediated immunity, and not to enhancing serum factors. The use of methods other than heat-killing for the preparation of pertussis vaccine may lead to different mechanisms of interference with immunity to tumour transplantation.

While immunisation with $M$. butyricum, and possibly Coryne. parvum, enhanced tumour immunity other organisms enhanced tumour growth; in both situations cellular immunity appeared to be the mechanism involved. Studies of chemically induced tumours of mice have indicated that various levels of immune reaction can have markedly different effects on tumour development. Thus, a strong immune response may result in tumour immunity, and a mild reaction enhance tumour development (Prehn, 1971, 1972). This may also apply to our results, $M$. butyricum having a stronger adjuvant effect on the immunising activity of the tumour extract than $B$. pertussis, $E$. coli or $S$. aureus. Since tumour extract alone can induce tumour immunity, the various microorganisms presumably act by stimulating or depressing the host response to the immunising action of the extract. Since immunotherapy is a possible method of treatment of cancer, it is most important to establish the exact mechanism of tumour immunity. 


\section{SUMMARY}

Cell-free extracts of adenovirus-12-induced tumours were used to immunise CBA mice against transplantation of the homologous tumour cells. Greater immunity was obtained when heat-killed Mycobacterium butyricum was added to the tumour extract. Less conclusive results were obtained with Corynebacterium parvum. In contrast, tumour cell extract plus Bordetella pertussis, Escherichia coli or Staphylococcus aureus gave significantly less immunity than did the tumour extract alone. Listeria monocytogenes and Candida albicans had no effect on immunity to tumour challenge.

The enhancement or depression of immunity appeared to operate through cellular rather than humoral or antibody mechanisms.

We would like to thank Professor Sir Charles Stuart-Harris and Professor M. G. McEntegart for their advice and criticism, and Mr A. Clegg for excellent technical assistance. This work was partly financed by the Cancer Research Campaign and the Ernest and Minnie Dawson Cancer Research Fund, Preston, Lancashire.

\section{REFERENCES}

Brown, E. G., Potter, C. W. AND OXford, J. S. 1972. Properties of transplantation antigen present in cell-free extracts of adenovirus 12 tumours. Eur. J. Cancer, 8, 9.

CoHEN, C. AND Tissot, R. G. 1963. The effect of vaccination with Bordetella pertussis on survival time of leukemic mice. Bact. Proc., p. 70.

Fisher, J. C., Grace, W. R. AND ManNick, J. A. 1970. The effect of non-specific immune stimulation with Corynebacterium parvum on patterns of tumour growth. Cancer Philad., 26, 1379.

Floersheim, G. L. 1967. Facilitation of tumour growth by Bacillus pertussis. Nature, Lond., 216, 1235.

Hirano, M., Sinkovics, J. G., Shullenberger, C. C. and Howe, C. D. 1967. Murine lymphoma: Augmented growth in mice with pertussis vaccine-induced lymphocytosis. Science, N.Y., 158, 1061.

Lowry, O. H., Rosenbrough, N. J., FarR, A. L. and Randall, R. J. 1951. Protein measurement with the Folin phenol reagent. J. biol. Chem., 193, 265.

Malkiel, S. AND HaRgis, B. J. 1961. Influence of Bordetella pertussis on host survival following S-180 implantation. Cancer Res., 21, 1461.

Nicol, T., McKelvie, P. AND Druce, C. G. 1961. Phagocytic activity of the reticuloendothelial system. Nature, Lond., 190, 418.

Old, L. J., Benacerraf, B., Clarke, D. A., Carswell, E. A. And Stockert, E. 1961. The role of the reticulo-entothelial system in the host reaction to neoplasia. Cancer Res., 21, 1281.

Old, L. J., Clarke, D. A. And Benacerraf, B. 1959. Effect of bacillus Calmette-Guerin infection on transplanted tumours in mice. Nature, Lond., 184, 291.

Orlando, R. A., Carft, K., Glick, M. and Wissler, R. W. 1972. Specific enhancement of hepatoma growth using methylated bovine serum albumin and pertussis vaccine. Lab. Invest., $26,735$.

POTTER, C. W. AND OXFORD, J. S. 1970. Transplantation immunity following immunisation with extracts of adenovirus 12 tumour cells. Int. J. Cancer, 6, 410 .

PReHN, R. T. 1971. Perspectives on oncogenesis: does immunity stimulate or inhibit neoplasia? J. reticuloendothel. Soc., $10,1$.

PrehN, R. T. 1972. The immune reaction as a stimulator of tumour growth. Science, N.Y., $176,170$.

Rees, R. C. AND Potter, C. W. 1972. Specific enhancement of transplantation immunity with heat-killed Mycobacterium butyricum and immunizing extracts from adenovirus 12induced tumour cells. Br. J. Cancer, 26, 139. 
Rees, R. C. AND Potter, C. W. 1973. In vivo studies of cell-mediated and humoral immune responses to adenovirus 12-induced tumour cells. Arch. ges. Virusforsch., 41, 116.

SMITH, L. H., AND Woodruff, M. F. A. 1968. Comparative effect of two strains of Corynebacterium parvum on phagocytic activity and tumour growth. Nature, Lond., 219, 197.

Weiss, D. W., Bonhag, R. S. AND De'OME, K. B. 1961. Protective activity of fractions of tubercle bacilli against isologous tumours in mice. Nature, Lond., 190, 889.

Weiss, D. W., Bonhag, R. S. AND LesLie, P. 1966. Studies on the heterologous immunogenicity of a methanol-insoluble fraction of attenuated tubercle bacilli (BCG). J. exp. Med., 124, 1039.

Woodruff, M. F. A., INCHLEY, M. P. AND Dunbar, N. 1972. Further observations on the effect of $C$. parvum and anti-tumour globulin on syngeneically transplanted mouse tumours. Br.J. Cancer, 26, 67. 